\section{Making researchers manage}

London

THE management of and financial arrangements for British science are outdated and in need of radical change, a former research council head declared last week. At last week's British Association meeting at Sheffield, Sir Douglas Hague, former chairman of the Economic and Social Research Council, told off researchers for being "arrogant", saying that they should be more accountable for the money they spend on basic research.

Hague, chairman of Metapraxis Ltd, said scientists could manage science provided they acquired an understanding of economics and management, and the ability to work together in "interdisciplinary teams which include and value those who do have such skills". But he complained that scientists would resist change because they had become accustomed to a long period of increasing expenditure on science.

"Scientists are being selfish with society's money", he claimed, declaring that society had the right "to impose on scientists the responsiblity of being accountable for their expenditures and actions".

He described the Advisory Board for the Research Councils (ABRC), of which he was a member for four years, as a "quixotic body" insufficently experienced in making management decisions. The "amateurism with which it too often operated, when concerned with management and organization", worried him: he singled out as an example the "British Empire Syndrome" - whenever a new research programme was started abroad, the ABRC wanted to carry it out in Britain.

One consequence, Hague said, is that Britain has about half as many research centres as the United States, but "given our relative populations and prosperity, one would expect Britain to have one fifth or fewer of the number in the United States". He also described the civil service as "the joker in the pack", claiming that civil servants are at least as "ignorant as scientists" in making managment decisions.

The attack on science management in Britain was sustained by Lord Dainton, the chemist who in his time has been a university vice-chancellor (Nottingham) and chairman of the University Grants Committee. He said it was a "simplistic notion that generous government support for basic and strategic science automatically brings national prosperity".

Because Britain does not have the financial capacity to accommodate the innate tendency of science to expand, he advocated unification of the five research councils to ensure the best deployment of scarce resources, adding that "new opportunities and problems often arise which can only be tackled by multidisciplinary approaches". The percentage of income spent on bureaucracy would also fall.

The proposal that all the research councils should be amalgamated, put forward earlier this year in a report to the ABRC, will probably be decided in the next few months.

Lord Dainton also concluded that government should divest itself of its existing support for industrial research and use the resources to increase support for universities and teaching. The role of government was to facilitate the movement of young people into industry, because market forces alone would not solve the problem. To get to grips with growing competition for limited funds, Hague argued that researchers should measure the cost of undertaking research not in monetary terms but in relation to the research opportunities which must be foregone, terms in which they normally do not think.

Ben Webb CANCER RESEARCH

\section{CRC and MRC to shuffle the pack}

\section{London}

THE Institute of Cancer Research (ICR), the largest comprehensive cancer centre in Britain, has created a new post of chief executive in a radical change in management structure. Biochemist Peter Garland will join ICR on 1 November to run a restructured management team.

The new appointment follows the resignation of ICR Director Robin Weiss, who had acted as both director and chief execu-

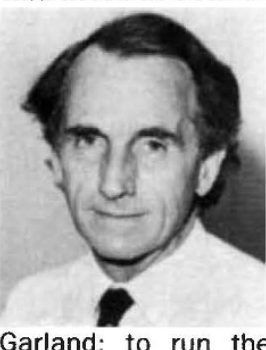
tive while remaining active in research. ICR Secretary Jonathan Kipling said the Committee of Management decided to take the opportunity to review the management structure.

Garland: to run the The ICR now reinstitute in line with ceives $£ 5$ million a CRC national strategy. year from both the Cancer Research Campaign, one of Britain's largest cancer charities, and the Medical Research Council, but MRC is phasing out its contribution over the next eight years and CRC will shoulder the lion's share of the budget.

Garland, who leaves Amersham International after two years as director of research, said he was delighted at the prospect of leading the ICR from the foundations laid by Weiss. Amersham has had to cut back on its research programmes after a fall of profits in the last financial year.

Ben Webb

\section{Smithsonian's new formula}

\section{Washington}

DECLARING that the "anguish" felt by Native Americans was "a weight that one ultimately cannot carry", Robert McCormick Adams, Secretary of the Smithsonian Institution, announced last week an enlarged policy for the return of skeletal remains to Native American tribes where there is a "preponderance of evidence" connecting the bones with modern descendants.

The agreement between the Smithsonian Institution, one of the largest holders of Native American remains, and a variety of American Indian groups comes shortly after a decision by Stanford University to return its archaeological collections to local tribes (Nature 340, 9; 1989), and is an example of an increasing recognition by museum curators that the demands of scientific research do not outweigh the proper and deeply felt religious feelings of modern American Indians.

Discussions aimed at loosening the Smithsonian's earlier policy, under which bones were to be returned only if a direct genealogical link with living descendants could be demonstrated, have been going on for many years. But resolution of the dispute was hastened at least in part by the Smithsonian's desire to pass through Congress legislation creating a National Museum of the American Indian in central Washington. With an amendment incorporating the new agreement, such legislation was approved last week by a House of Representatives subcommittee on libraries and memorials; Smithsonian officials feel confident that the new museum will eventually gain the full approval of the Congress.

But a more important element in reaching the new agreement was, according to a spokesperson for the Smithsonian, the growing conviction of Secretary Adams that the Native Americans' grievance is profound. Adams now has the task of appointing a five-member committee, of whom three will be Native Americans, which will judge demands for the return of remains.

In his announcement of the new policy, Adams estimated that 5-10 per cent of the Smithsonian's collection might ultimately be returned for reburial, but wording of the agreement leaves it entirely up to the committee to decide what is or is not a "preponderance of evidence" in favour of returning bones. Some American Indians want all remains, even those thousands of years old, taken from museums and put back whence they came, but curators at the Smithsonian believe this is a minority view, and that most of the collection will be left intact.

David Lindley 